\title{
Improving Diquat EFficacy on Grasses by AdDing Adjuvants to THE SPRAY SOlUtion Before UsE ${ }^{1}$
}

\author{
Melhorando Eficácia do Diquat em Gramíneas por Meio da Adição de Adjuvantes à Solução de \\ Pulverização Antes da Utilização
}

\author{
GITSOPOULOS, T.K. ${ }^{*}$, DAMALAS, C.A. ${ }^{3}$, and GEORGOULAS, I. ${ }^{2}$
}

\begin{abstract}
The effect of five adjuvants (non-ionic surfactant, paraffinic oil, vegetable oil, mixture of fatty acids methyl esters plus surfactant blend, and organosilicone) on diquat efficacy was assessed on poverty brome, sterile oat, and Italian ryegrass in field and pot experiments. All tank mixtures with diquat increased diquat efficacy from $50-54 \%$ to $77-98 \%$ as for fresh weight reduction, indicating significant enhancement of diquat efficacy on grasses. The increased efficacy was most likely attributed to better droplet retention and diffusion on the leaf surfaces. When combined with non-ionic surfactant, diquat showed slightly more rapid control of grass weeds (i.e. symptoms were visible within a few hours after application).
\end{abstract}

Keywords: non-ionic surfactant, paraffinic oil, vegetable oil, fatty acids methyl esters, organosilicone, bipyridyliums.

RESUMO - O efeito de cinco adjuvantes (surfatante não iônico, óleo parafinico, óleo vegetal, mistura de ácidos graxos metil ésteres mais surfatante mistura e organossilicone) no que diz respeito à eficácia do diquat foi avaliado sobre bromo-estéril, aveião e azevém-italiano em experimentos de campo e estufa. Todas as misturas de tanque com diquat aumentaram a eficácia desse herbicida de 50-54\% a 77-98\% em termos de redução de peso fresco, indicando aumento significativo da eficácia do diquat em gramineas. Esse aumento foi atribuido a uma melhor retenção de gotícula e de difusão sobre as superficies foliares. Diquat com o surfatante não iônico mostrou controle ligeiramente mais rápido das plantas daninhas gramíneas (isto é, os sintomas eram visiveis dentro de poucas horas após a aplicação).

Palavras-chave: surfatante não-iónico, óleo de parafina, óleo vegetal, ácidos graxos metilados, organossilicone, bipiridilos.

\section{INTRODUCTION}

Diquat

$(9,10$-dihydro-8a, 10adiazoniaphenanthrene dibromide) belongs to the group of bipyridylium herbicides, and it is a contact herbicide that kills the green parts of plants where it is deposited and with which it comes into contact (Ashton \& Crafts, 1981). Symptoms normally include a rapid wilting of the foliage and a frostbitten appearance, caused by the rapid destruction of plant cell membranes, particularly in sunlight (Fishel, 2011). When present in chloroplasts, it undergoes a rapid reduction and, after a series of interactions, hydrogen peroxide and highly reactive hydroxyl radicals are produced and attack the membrane lipids (Devine et al., 1993). Due to quick death of leaf tissues, diquat has rather limited translocation to other plant tissues, although under suitable conditions it can be translocated within the plant (Mees, 1960; Thrower et al., 1965).

Recebido para publicação em 7.12.2013 e aprovado em 25.1.2014.

2 Institute of Plant Protection of Thessaloniki, Hellenic Agricultural Organization-Demeter, Thermi, Thessaloniki, Greece, <gitsopoulos@yahoo.gr>; ${ }^{3}$ Department of Agricultural Development, Democritus University of Thrace, Orestiada, Greece. 
This herbicide is used as a desiccant to clear fallows and seedbeds before sowing, for weed control on non-crop land, around trees, and bushes and with direct-spraying for interrow weeding in row crops (Cronshey, 1961). It is also used as an aquatic herbicide (Ahrens, 1994; Henares et al., 2011) and as a desiccant in potato, alfalfa, and other crops to aid harvesting (Calderbank \& Slade, 1976). Its application rates are 400-1000 g a.i./ha (Tomlin, 2000). Diquat is particularly effective against broadleaf weeds, whereas it is less damaging to grasses at the same rate of application (Calderbank \& Slade, 1976). By contrast, it has no residual soil activity because it is inactivated (quickly and tightly adsorbed to soil colloids) in contact with the soil (Pateiro-Moure et al., 2007).

Adjuvants are commonly used with postemergence foliar herbicides to increase the activity of the active ingredient or to offset potential problems frequently associated with application characteristics (Hazen, 2000). Some of the main beneficial effects of adjuvants are the reduction in surface tension and contact angle of the spray solution, thereby improving foliage coverage by the spray solution and enhancing herbicide absorption (Foy \& Smith, 1965; Hess \& Foy, 2000; Penner, 2000). An increase in spray coverage is especially important with contact herbicides that do not move within plants. Recent and previous studies reported the addition of adjuvants to the diquat spray solution (Gilreath \& Gilreath, 1989; Langeland et al., 2002; Menendez \& Bastida, 2004; Puri et al., 2008) and some new products include non-ionic adjuvants to optimize droplet spread and retention for specific cases (Menendez \& Bastida, 2004). However, experimental data on diquat efficacy with the use of adjuvants remain limited.

In Greece, diquat is distributed with various commercial products, all in a soluble liquid formulation, but there is no indication on the label of the products for addition of adjuvants to the spray solution. However, increased diquat efficacy against grass weeds would be a good alternative for broad spectrum weed control in trees, orchards or non-planted areas, possibly with the use of lower application rates. Thus, the aim of this study was to detect possible enhancement of diquat activity on grass weeds by the addition of adjuvants to the spray solution.

\section{MATERIALS AND METHODS}

\section{Field experiment}

A field experiment was conducted at Thermi (Plant Protection Institute of Thessaloniki) in northern Greece in 2009. The physicochemical characteristics of the soil were: clay $6.8 \%$, silt $32 \%$, sand $61.2 \%$, organic matter $1.85 \%, \mathrm{CaCO}_{3} 3.5 \%$ and $\mathrm{pH} 7.7$. An area heavily and uniformly infested with poverty brome (Bromus sterilis) and sterile oat (Avena sterilis) (> 80\% soil coverage with both species) was selected for this study. The experiment was arranged in a randomized complete block design with four replicates. Plots were $3 \mathrm{~m}$ long and $2.4 \mathrm{~m}$ wide. Herbicide treatments consisted of post-emergence applications of diquat at $0.8 \mathrm{~kg}$ a.i. ha ${ }^{-1}$, in a soluble liquid (SL) formulation, alone and in mixture with each one of the following five commercial adjuvants: a) a non-ionic surfactant, b) paraffinic oil, c) vegetable oil, d) mixture of fatty acids methyl esters plus surfactant blend, and e) an organosilicone surfactant. The trade names and the rates of the adjuvants applied with diquat are shown in Table 1. An adjacent non-treated plot next to each treated plot was used as control for comparison. All herbicide treatments were applied with a hand-held AZO portable field plot sprayer (AZO-sprayers, P.O. Box 350-6710 BJ EDE, The Netherlands) that had a $2.4 \mathrm{~m}$ wide boom, fitted with Teejet ${ }^{\circledR} 8002$ nozzles, and calibrated to deliver $600 \mathrm{~L} \mathrm{ha}^{-1}$ at $215 \mathrm{kPa}$ pressure. The high carrier volume was applied for thorough coverage of the weed foliage as indicated by the product label and our preliminary experiments. By the time of herbicide applications, weed species were at the tillering stage.

Control of grasses was assessed visually and with measurements of fresh weight at 10 days after treatment (DAT). Visual control ratings were recorded on a scale of 0 to $100 \%$ based on each adjacent non-treated control, where $0 \%$ corresponded to no visual injury and $100 \%$ to complete plant death. Additionally, weed plants from a half square meter area in 
Table 1 - Adjuvants and application rates tested

\begin{tabular}{|l|l|l|c|}
\hline \multicolumn{1}{|c|}{ Category } & \multicolumn{1}{|c|}{ Active ingredient } & \multicolumn{1}{|c|}{$\begin{array}{c}\text { Trade name } \\
\left(\mathrm{L} \mathrm{ha}^{-1}\right)\end{array}$} \\
\hline Non-ionic surfactant & Isodecyl-alcohol-ethoxylate 90\% & \multicolumn{1}{c|}{1.0} \\
\hline Paraffinic oil & Paraffinic oil 60\% & TREND $^{\circledR}$ & 1.0 \\
\hline Vegetable oil & Rapeseed oil 86.4\% & ATPLUS $^{\circledR}$ & 1.5 \\
\hline $\begin{array}{l}\text { Mixture of fatty acids methyl } \\
\text { esters plus surfactant blend }\end{array}$ & $\begin{array}{l}\text { Mixture of fatty acid esters (37.5\%) and alkoxylated } \\
\text { alcohols-phosphate esters (22.5\%) }\end{array}$ & CODACIDE $^{\circledR}$ & DASH HC $^{\circledR}$ \\
\hline Organosilicone surfactant & Polyether-polymethysiloxane-copolymer 100\% & BREAK-THRU S240 $^{\circledR}$ & 0.7 \\
\hline
\end{tabular}

the middle of each plot were cut at ground level and the total fresh weight of poverty brome and sterile oat plants (mixed population) was recorded. Fresh weight data were expressed as a percent reduction from the non-treated control. All data (percentages) were subjected to analysis of variance (ANOVA) at $p<0.05$. Before the ANOVA, the percentages were arcsine square root-transformed to normalize variance. Both transformed and original means are presented. Means were separated using Fisher's protected LSD test at $\mathrm{p}<0.05$.

\section{Glasshouse experiment}

A glasshouse experiment was conducted in pots at Thermi in 2009. Seeds of Italian ryegrass [Lolium perenne L. ssp. multiflorum (Lam.) Husnot)] were planted in plastic pots (12 cm diameter and $10 \mathrm{~cm}$ height) filled with sieved soil taken from the field experiment (as described above). Four days after emergence, plants were thinned to a uniform stand of five plants per pot. The same herbicide treatments as described in the field experiment were applied when the plants were at the five-leaf growth stage. Nontreated seedlings were used as control for comparison. A randomized complete block design with five replications was used. After herbicide treatments, the pots were transferred back to the glasshouse. Plants grew normally throughout the experiment without experiencing any particular environmental stress conditions.

Italian ryegrass control was assessed visually as described above and by determining the fresh weight of shoots cut at the soil surface 10 DAT. Fresh weight per pot was expressed as a percent fresh weight reduction from the non-treated control. All data (percentages) were subjected to analysis of variance (ANOVA) at $\mathrm{p}<0.05$. Before the ANOVA, the percentages were arcsine square root-transformed to normalize variance. Both transformed and original means are presented. Means were separated using Fisher's protected LSD test at $\mathrm{p}<0.05$.

\section{RESULTS AND DISCUSSION}

In the field experiment, the addition of adjuvants to the spray solution significantly increased control of poverty brome and sterile oat to $75-93 \%$, from only $38 \%$ for diquat applied alone (Table 2). In terms of fresh weight, all adjuvants in combination with diquat caused significantly higher fresh weight reduction $(79-90 \%)$ of poverty brome and sterile oat compared to diquat applied alone (54\%) (Table 2). In the glasshouse experiment, the addition of adjuvants to the spray solution significantly enhanced Italian ryegrass control to $70-96 \%$, from only $40 \%$ for diquat applied alone (Table 3). Moreover, the addition of adjuvants to the spray solution significantly promoted fresh weight reduction of Italian ryegrass to $77-98 \%$, from $50 \%$ when diquat was applied alone (Table 3).

The results from both experiments showed major improvement in diquat activity against the grass weeds studied with the addition of adjuvants to the spray solution. A recent report from Menendez \& Bastida (2004) revealed enhancement of diquat efficacy against rigid ryegrass (Lolium rigidum) and common purslane (Portulaca oleracea) with the addition of six commercial adjuvants. The same authors reported that the adjuvants tested allowed the reduction of herbicide rates down 
Table 2 - Diquat efficacy on mixed population of poverty brome and sterile oat

\begin{tabular}{|l|c|c|}
\hline \multicolumn{1}{|c|}{ Treatment } & Visual control $^{\underline{1}}$ & Fresh weight reduction $^{\underline{1}}$ \\
\hline Diquat + TREND & $74.3(93)$ & $71.9(90)$ \\
\hline Diquat + ATPLUS & $70.8(89)$ & $67.4(85)$ \\
\hline Diquat + CODACIDE & $60.5(75)$ & $63.7(79)$ \\
\hline Diquat + DASH HC & $66.4(84)$ & $68.6(86)$ \\
\hline Diquat + BREAK-THRU S240 & $73.2(91)$ & $69.6(87)$ \\
\hline Diquat [no adjuvant] & $37.7(38)$ & $47.3(54)$ \\
\hline LSD $_{0.05}$ & 8.5 & 6.5 \\
\hline
\end{tabular}

1/ Values are arcsine square-root transformed. Original percentages are shown in parentheses.

Table 3 - Diquat efficacy on Italian ryegrass

\begin{tabular}{|l|c|c|}
\hline \multicolumn{1}{|c|}{ Treatment } & Visual control $^{\underline{1} /}$ & Fresh weight reduction $^{\mathbf{1}^{\prime}}$ \\
\hline Diquat + TREND & $81.1(96)$ & $83.1(98)$ \\
\hline Diquat + ATPLUS & $69.1(83)$ & $74.3(89)$ \\
\hline Diquat + CODACIDE & $57.8(70)$ & $64.2(77)$ \\
\hline Diquat + DASH HC & $61.8(76)$ & $67.6(83)$ \\
\hline Diquat + BREAK-THRU S240 & $75.9(89)$ & $79.5(93)$ \\
\hline Diquat [no adjuvant] & $39.1(40)$ & $45.0(50)$ \\
\hline LSD $_{0.05}$ & 17.0 & 17.1 \\
\hline
\end{tabular}

1/ Values are arcsine square-root transformed. Original percentages are presented in parentheses.

to one half up to one third compared with controls without adjuvant addition. In general, the presence of adjuvants in the spray mixture may have multiple functions on the leaf surface, all contributing to the improvement of pesticide uptake (Wang \& Liu, 2007). These include: (a) ensuring an intimate contact between the droplets and the leaf surface, especially on waxy species; (b) preventing or delaying crystal formation in the droplet residue; (c) delaying droplet drying through a hygroscopic effect (Wang \& Liu, 2007). The adjuvants used in this study possibly contributed, to a different extent, to better retention and spreading of the spray solution on foliage, thereby improving herbicide retention, diffusion, and cuticle penetration compared with diquat applied alone. Observations in the laboratory with detached leaves of grasses placed in an upright position showed that spray droplets of diquat without adjuvant slipped easily and fell off the leaf surface shortly, whereas spray droplets of diquat with adjuvant remained tightly bound on the leaf surface and later spread over the surface.

Planta Daninha, Viçosa-MG, v. 32, n. 2, p. 355-360, 2014
Spray retention on foliar surfaces usually determines, to a great extent, the efficient uptake and biological activity of agrochemicals (Grangeot et al., 2006), especially on leaves with difficult-to-wet surfaces covered with microcrystalline wax. If the spray droplet properties are not optimized, then the spray will bounce off the surface and be lost to the ground, whereas spray retention is less of a concern on plants with smooth wax surfaces because even water alone will probably adhere. Contact herbicides like diquat kill mainly the portion of the plant that is actually contacted by the herbicide. For this reason, thorough leaf coverage at application is important. However, plant surfaces are often covered by a wide range of different structures, ranging from glands, trichomes, stomata, smooth wax or highly crystalline microcrystalline wax crystals, and these structures control the wetting of these surfaces (Koch et al., 2008). The epicuticular wax layer of leaves is considered to be the most significant barrier to absorption and penetration of foliar-applied chemicals (Stevens \& Baker, 1987; Baker \& Charnel, 1990; Penner, 2000) and, especially, 
of water-soluble herbicides like diquat. In general, the dominant epicuticular wax on leaves of grass species is crystalline, whereas that of broadleaf weeds is amorphous (De Ruiter et al., 1990; Harr et al., 1991; Wang \& Liu, 2007). Leaves with dominant crystalline wax are more difficult to wet, retain much less spray solution than other species (characterized by a smooth cuticular surface), and the herbicide diffusion through waxes becomes limited (De Ruiter et al., 1990; Hess \& Foy, 2000).

Although better retention and spreading of the spray solution on the foliage can satisfactorily explain the increased efficacy of diquat on the grass weeds studied when the adjuvants were added to the spray solution, there may have been other factors that caused increased herbicide efficacy apart from the chemical properties of the adjuvant. Previous studies on the effects of adjuvants on other foliar-applied herbicides showed that factors like specific interactions of herbicide-adjuvant-plant surface contributed to increased herbicide activity (Foy \& Smith, 1965; Singh et al., 2002). For example, in this study, the addition of the non-ionic adjuvant seemed to exert a significant effect on diquat efficacy, revealing high control of grasses and a high effect on fresh weight reduction. Moreover, in this study, plants treated with diquat plus the non-ionic adjuvant developed, slightly earlier (i.e. within a few hours after application), the initial 'water soaking' symptoms described by Hess (2000) for bipyridyliums and the consequent necrotic tissues which follow these early symptoms, compared to the other treatments. Regarding the non-paraffinic oil adjuvants studied, it is generally accepted that methylated seed oils exhibit a greater effect on herbicide uptake than non-modified seed oils (Gauvrit and Cabanne, 1993), which is in line with our results, but the difference between seed oils and mineral oils often varies with herbicides and weed species (Gauvrit \& Cabanne, 1993).

Data from both studies reported herein lead to the clear conclusion that there is major improvement of diquat activity against the grass weeds studied with the addition of adjuvants to the spray solution. This is of major importance considering that diquat is less damaging to grasses than broadleaf weeds at the same rate of application (Calderbank \& Slade, 1976). Increased herbicidal activity of diquat with the addition of adjuvants could widen the weed spectrum of control and might allow the use of lower application rates, both of which are desirable from an economical and environmental point of view. Also, this option may have practical implications in the reduction of herbicides rates in various weed control programs as an approach to decreased production costs (Blackshaw et al., 2006; Kudsk, 2008). However, the aim of this study was not to suggest a specific spray adjuvant for use with diquat over other adjuvant products, but rather to find alternatives for optimized weed control with diquat. Uptake of pesticides into plant foliage varies with plants and chemicals, and can be greatly influenced by adjuvants and environmental conditions (Wang \& Liu, 2007). Moreover, the effects of adjuvants on foliar uptake of herbicides depend not only on their chemical structures and concentration, but also on the physicochemical properties and concentration of the active ingredients and the leaf surface character of the plant species (Liu, 2004). In this context, selecting appropriate adjuvants can be confusing even for experts, as there are hundreds of products available in the market and manufacturers often fail to provide fully detailed information about the composition of their products. A more multidisciplinary approach is needed to elucidate the behavior of pesticides with respect to the mode of action of adjuvants.

\section{LITERATURE CITED}

AHRENS, W. H. Herbicide handbook. 7.ed. Champaing: Weed Science Society of America, 1994. p. 108-110.

ASHTON, M. F.; CRAFTS, A. S. Mode of action of herbicides. 2.ed. New York, John Wiley \& Sons, 1981. $525 \mathrm{p}$.

BAKER, E. A.; CHARNEL, A. R. Herbicide penetration across isolated and intact leaf cuticles. Pestic. Sci., v. 29, n. 1, p. 187-196, 1990.

BLACKSHAW, R. et al. Reduced herbicide doses in field crops: a review. Weed Biol. Manag., v. 6, n. 1, p. 10-17, 2006.

Planta Daninha, Viçosa-MG, v. 32, n. 2, p. 355-360, 2014 
CALDERBANK, A.; SLADE, P. Diquat and Paraquat. In: KEARNY, P. C.; KAUFMAN, D. D. (Ed.). Herbicides: chemistry, degradation, and mode of action. New York: Marcel Dekker, 1976. p. 501-540.

CRONSHEY, J. F. H. A review of experimental work with diquat and related compounds. Weed Res., v. 1, n. 1, p. 68-77, 1961.

DE RUITER, H. et al. Influence of surfactants and plant species on leaf retention of spray solutions. Weed Sci., v. 38, n. 6, p. $567-572,1990$.

DEVINE, M. D. et al. Physiology of herbicide action. Englewood Cliffs: Prentice Hall, 1993. p. 441.

FISHEL, F. M. Pesticide toxicity profile: bipyridylium herbicides. Gainesville: Pesticide Information Office, Florida Cooperative Extension Service, Institute of Food and Agricultural Sciences, University of Florida, 2011. 3 p. (Publication PI 88)

FOY, C. L.; SMITH, L. W. Surface tension lowering, wettability of paraffin and corn leaf surfaces, and herbicidal enhancement of dalapon by seven surfactants. Weeds, v. 13, n. 1, p. 15-19, 1965.

GAUVRIT, C.; CABANNE, F. Oils for weed control: uses and mode of action. Pestic. Sci., v. 37, n. 1, p. 147-153, 1993.

GILREATH, J. P.; GILREATH P. R. Effect of adjuvant on nightshade control with paraquat and diquat. Proc. Florida State Hortic. Soc., v. 102, p. 338-340, 1989.

GRANGEOT, M. et al. Spray retention, foliar uptake and translocation of glufosinate and glyphosate in Ambrosia artemisiifolia. Weed Res., v. 46, n. 2, p. 152-162, 2006.

HARR, J. et al. The leaf surface of major weeds. Witterswilt: Sandoz Agro, 1991. 131 p.

HAZEN, J. L. Adjuvants: terminology, classification, and chemistry. Weed Technol., v. 14, n. 4, p. 773-784, 2000.

HENARES, M. N. P. et al. Efficacy of diquat in the control of Hydrylla verticillata, Egeria densa and Egeria najas and its acute toxicity to Phallocerus caudimaculatus, under laboratory conditions. Planta Daninha, v. 29, n. 2, p. 279-285, 2011.

HESS, F. D. Light-dependent herbicides: an overview. Weed Sci., v. 48, n. 1, p. 160-170, 2000.

HESS, F. D.; FOY C. L. Interaction of surfactants with plant cuticles. Weed Technol., v. 14, n. 4, p. 807-813, 2000.
KOCH, K. et al. Diversity of structure, morphology and wetting of plant surfaces. Soft Matter, v. 4, n. 1, p. 1943-1963, 2008.

KUDSK, P. Optimising herbicide dose: A straightforward approach to reduce the risk of side effects of herbicides. Environmentalist, v. 28, n. 1, p. 49-55, 2008.

LANGELAND, K. A. et al. Evaluation of a new formulation of reward landscape and aquatic herbicide for control of duckweed, waterhyacinth, waterlettuce and hydrilla. J. Aquat. Plant Manag., v. 40, n. 1, p. 51-53, 2002.

MEES, G. C. Experiments on the herbicidal action of 1,1'ethylene-2,2'-dipyridylium dibromide. Ann. Appl. Biol., v. 48, n. 3, p. 601-612, 1960.

MENENDEZ, J.; BASTIDA, F. Use of adjuvant-enhanced formulations to increase bipyridylium-herbicide effectiveness. Comm. Appl. Biol. Sci., v. 69, n. 1, p. 61-65, 2004.

PENNER, D. Activator adjuvants. Weed Technol., v. 14, n. 1, p. 758-791, 2000.

PATEIRO-MOURE, M. et al. Influence of copper on the adsorption and desorption of paraquat, diquat, and difenzoquat in vineyard acid soils. J. Agric. Food Chem., v. 55, n. 15 , p. 6219-6226, 2007.

PURI, A. et al. Effect of foliar application of diquat herbicide on selected natural area and field crop species. Weed Biol. Manag., v. 8, n. 1, p. 133-138, 2008.

SINGH, M. et al. Adjuvants enhance weed control efficacy of foliar-applied diuron. Weed Technol., v. 16, n. 1, p. 74-78, 2002.

STEVENS, P. J. G.; BAKER, E. A. Factors affecting the foliar absorption and redistribution of pesticides. 1. Properties of leaf surfaces and their interactions with spray droplets.

Pestic. Sci., v. 19, n. 1, p. 265-281, 1987.

THROWER, S. L. et al. Movement of diquat dibromide in leguminous plants. Ann. Appl. Biol., v. 55, n. 1, p. 253-260, 1965.

TOMLIN, C. D. S. The pesticide manual. 12.ed. Surrey: British Crop Protection Council, 2000. p. 324-325.

LIU, Z. Effects of surfactants on foliar uptake of herbicides a complex scenario. Colloids Surf. B, v. 35, n. 3-4, p. 149-153, 2004.

WANG, C. J.; LIU, Z. Q. Foliar uptake of pesticides Present status and future challenge. Pestic. Biochem.

Physiol., v. 87, n. 1, p. 1-8, 2007. 